\title{
BACTERIA DIVERSITY IN SEDIMENT FROM MANGROVE AND BEKANTAN CONSERVATION AREA, TARAKAN CITY
}

\author{
Yulma $^{1}$ - Gloria Ika Satriani ${ }^{2}$ - Awaludin $^{2}$ - Burhanuddin \\ Ihsan $^{2}$ - Bela Pratiwi ${ }^{2}$
}

Ringkasan Bacteria in sediment plays an important role in various biochemical processes in the waters area, for instance degradation of organic matter, biogeochemical cycle, controlling ammonium, nitrates and nitrites concentration, food source for fauna, primary production, and pollution remediation. The purpose of this study was to determine the diversity of bacteria (Genus) in sediment on the Mangrove and Bekantan Conservation Area (KKMB), Tarakan City. The method used was explorative descriptive method with genus identification as parametric test. Bacterial identification parameters were tested using Gram-test, main test and further test was carried out at the Laboratory of Fish Quarantine, Quality Control and Safety Fishery Products Class II Tarakan. The bacteria found in the sediments on the KKMB were $16 \mathrm{ge}$ nera i.e. Enterobacteria, Eubacterium, Listeria, Actinobacillus, Bacteriodes, Streptococcus, Plesiomonas, Corynebacterium, Pseudomonas, Aeromonas, Bordetella parapertussis, Micrococcus, Staphylococcus, Clostridium, Neisseria, and

\footnotetext{
${ }^{1}$ )Jurusan Manajemen Sumberdaya Perairan, FPIK UBT $^{2}$ )Jurusan Akuakultur, FPIK UBT

E-mail: yulma.yuki@gmail.com
}

the dominant numbers found was Bacillus.

Keywords Bacteria, Diversity, KKMB, Mangrove, Sediment, Tarakan

Received : 16 Januari 2019

Accepted : 13 Februari 2019

\section{PENDAHULUAN}

Mangrove merupakan hutan lahan basah yang memiliki nilai ekonomis dan ekologi yang tinggi (Rangkuti et al., 2017). Indonesia memiliki hutan mangrove yang luas serta potensi yang sangat besar jika dikelola dengan baik (Saparinto, 2007). Salah satunya perlu batu kunci dalam ekosistem mangrove yaitu bakteri sebagai agen pendekomposisi. Bissett et al. (2007) menjelaskan bahwa keanekaragaman komunitas mikroorganisme di dalam sedimen sangat tinggi. Hal ini disebabkan sedimen mendukung dan membantu pembentukan kerjasama lingkungan mikro aerobik dan anaerobik. Aktivitas bakteri dalam siklus unsur hara pada sedimen adalah suatu hal yang tidak bisa dipisahkan dan saling berkaitan. Aktivitas bakteri tersebut tergantung pada ketersediaan karbon-karbon 
yang dioksidasi. Karbon bersama dengan unsur lainnya seperti fosfor $(\mathrm{P})$ dan nitrogen $(\mathrm{N})$ melalui proses fotosintesis menghasilkan jaringan tumbuhtumbuhan yang menjadi makanan hewan. Keduanya menghasilkan zat organik, jika mati dan membusuk dihasilkan bahan mentah untuk memulai daur bahan organik (Romimohtarto and Juwana, 2001).

Bakteri merupakan salah satu mikroorganisme yang berperan sebagai pengurai di dalam sedimen. Purnomo et al. (2016) mendapatkan total bakteri lebih tinggi pada sedimen permukaan dibandingkan dengan sedimen pada kedalaman $30 \mathrm{~cm}$. Bakteri yang hidup dalam sedimen memegang peranan penting dalam meningkatkan pertumbuhan dan produksi tanaman sehubungan dengan kemampuannya mengikat $\mathrm{N}_{2}$ dari udara dan mengubah ammonium menjadi nitrat.

Mengingat pentingnya peran bakteri dalam lingkungan sebagai dekomposer dalam menyeimbangkan siklus nitrogen pada sedimen di ekosistem mangrove Kota Tarakan, sehingga perlu diketahui keanekaragaman jenis bakteri pada sedimen, distribusi serta potensi bakteri dalam mendegradasi senyawa organik menjadi anorganik pada ekosistem yang memiliki tingkat keanekaragaman yang tinggi. Penelitian ini bertujuan untuk mengisolasi dan mengidentifikasi serta karakterisasi jenis bakteri yang diduga berperan sebagai agen dekomposisi dalam siklus nitrogen dan rantai makanan pada sedimen di Kawasan Konservasi Mangrove dan Bekantan (KKMB) Kota Tarakan.

\section{MATERI DAN METODE}

Penelitian ini menggunakan metode deskriptif eksploratif yang dilakukan dua tahapan yaitu pengambilan sampel sedimen di KKMB kemudian dilanjutkan dengan identifikasi bakteri di Laboratorium Stasiun Karantina Ikan, Pengendalian Mutu dan Keamanan Hasil Perikanan Kelas II Tarakan. Alat yang digunakan dalam penelitian meliputi laminari air flow, inkubator, otoklaf, speader, lampu bunzen, mikroskop binokuler, timbangan analitik, alat-alat glas. Bahan yang digunakan dalam penelitian meliputi sedimen, MIO, TSA, larutan $\mathrm{H}_{2} \mathrm{O}_{2} 3 \%$, Larutan $\mathrm{KOH} 3 \%$, media $\mathrm{O} / \mathrm{F}$, stripe oksidase, glukosa, pewarna Gram, parafin, alkohol $70 \%$ dan aquades.

Lokasi penelitian di daerah Kawasan Konservasi Mangrove dan Bekantan (KKMB) dengan empat stasiun. Sampel sedimen diambil berdasarkan jenis dominasi mangrove. Pada stasiun I jenis mangrove yang paling dominan adalah jenis mangrove Avicennia sp., pada stasiun II didominasi oleh jenis mangrove Rhizophora sp., pada stasiun III didominasi oleh jenis mangrove Bruguiera sp. dan stasiun IV didominasi oleh jenis mangrove Sonneratia sp. Lokasi penelitian dapat dilihat pada Gambar 1.

Sampel sedimen masing-masing diambil satu kali setiap satu stasiun sebanyak 250 gram dan dimasukkan ke dalam botol sampel yang steril. Sampel sedimen kemudian dibawa ke Laboratorium Stasiun Karantina Ikan, Pengendalian Mutu dan Keamanan Hasil Perikanan Kelas II Tarakan. Di laboratorium sampel sedimen disimpan dalam refrigerator dengan suhu $5-10{ }^{\circ} \mathrm{C}$ sampai digunakan. 


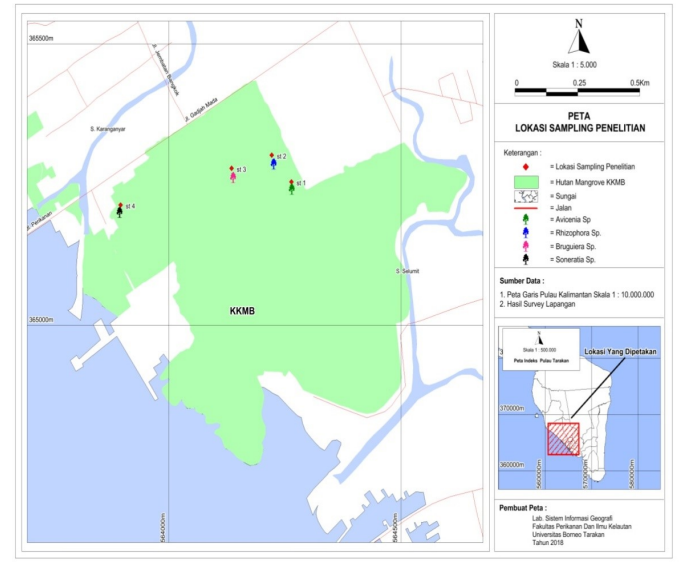

Gambar 1 Lokasi Penelitian di Kawasan Konservasi Mangrove dan Bekantan (KKMB)

Isolasi bakteri dari sedimen dilakukan dengan cara menimbang sedimen sebanyak 5 gram, kemudian dihaluskan menggunakan mortar dan pistle. Selanjutnya sedimen yang telah halus dimasukkan ke dalam labu erlenmayer yang berukuran $250 \mathrm{~mL}$. Proses pengenceran dilakukan sampai tingkat 10-7, selanjutnya dibiakkan pada media TSA. Biakkan bakteri diinkubasi selama 24 48 jam, kemudian koloni bakteri yang tumbuh dimurnikan dengan membuat subbiakan ke media TSA dan diambil koloni yang berbeda-beda, kemudian diinkubasi selama 24 jam.

Identifikasi bakteri pada sedimen dilakukan dengan 3 pengujian yaitu: uji pewarnaan Gram (gram negatif, gram positif dan bentuk bakteri), uji utama (KOH $3 \%, \mathrm{H}_{2} \mathrm{O}_{2} 3 \%$ dan Oksidase) dan uji lanjut (O/F, Glukosa dan motility) (Cowan and Steel's, 1974).

\section{HASIL DAN PEMBAHASAN}

Hasil penelitian menunjukkan bahwa populasi bakteri pada sedimen KKMB sangat bervariasi dengan ditemukannya berbagai macam bakteri. Bissett et al.
(2007) menjelaskan bahwa keanekaragaman komunitas mikroorganisme sedimen sangat tinggi. Hal ini disebabkan kandungan sedimen mendukung dan membantu pembentukan kerjasama lingkungan mikro aerobik dan anaerobik. Misalnya, penurunan kadar oksigen karena aktivitas mikroorganisme di ruang kaya bahan organik, akan membentuk lingkungan mikro anaerobik yang mendukung aktivitas mikroorganisme anaerobik fakultatif dan obligat. Hal ini menyebabkan timbulnya kelompok-kelompok mikroorganisme dengan sifat fisiologi spesifik tertentu yang sesuai dengan kondisi lingkungan mikro tersebut (Maier et al., 2009).

Bakteri pada sedimen di KKMB ditemukan sebanyak 16 genus antara lain Enterobacteria, Eubacterium, Listeria, Actinobacillus, Bacteriodes, Streptococcus, Plesiomonas, Corynebacterium, Pseudomonas, Aeromonas, Bordetella parapertussis, Micrococcus, Staphylococcus, Clostridium, Neisseria. Jenis bakteri yang paling dominan ditemukan di KKMB adalah Bacillus dan yang paling sedikit adalah Neisseria, seperti pada Tabel 1 .

Bakteri yang dominan di semua stasiun pengamatan adalah Bacillus, hal ini disebabkan karena jenis Bacillus merupakan bakteri pengurai fosfat yang umum ditemukan pada sedimen. Hasil ini sesuai dengan penelitian Yulma et al. (2017) bahwa bakteri yang dominan ditemukan pada dekomposisi serasah daun mangrove di KKMB adalah bakteri jenis Bacillus. Selanjutnya, Yulma et al. (2018a) juga mendapatkan bakteri jenis Bacillus yang paling dominan di perairan KKMB. Bakteri pengurai fosfat berperan dalam penyediaan kembali senyawa fosfat pada eko- 
Tabel 1 Jenis bakteri yang dominan di KKMB

\begin{tabular}{|c|c|c|c|c|c|}
\hline \multicolumn{2}{|c|}{ Bakteri } & \multicolumn{4}{|c|}{ Stasiun } \\
\hline Famili & Genus & I & II & III & IV \\
\hline Bacillaceae & Bacillus & $\mathrm{x}$ & $\mathrm{x}$ & $\mathrm{x}$ & $\mathrm{x}$ \\
\hline Aeromonadaceae & Aeromonas & - & - & - & $\mathrm{x}$ \\
\hline Bacteroidaceae & Bacteriodes & - & $\mathrm{x}$ & $\mathrm{x}$ & - \\
\hline Listeriaceae & Listeria & $\mathrm{x}$ & $\mathrm{x}$ & - & $\mathrm{x}$ \\
\hline Corynebacteriaceae & Corynebacterium & $\mathrm{x}$ & - & $\mathrm{x}$ & - \\
\hline \multirow{2}{*}{ Enterabacteriaceae } & Enterobacteria & $\mathrm{x}$ & - & $\mathrm{x}$ & - \\
\hline & Plesiomonas & $\mathrm{x}$ & - & - & - \\
\hline Streptococcoсеаe & Streptococcus & $\mathrm{x}$ & $\mathrm{x}$ & - & - \\
\hline Pasteurellaceae & Actinobacillus & - & $\mathrm{x}$ & $\mathrm{x}$ & $\mathrm{x}$ \\
\hline Pseudomonaceae & Pseudomonas & $\mathrm{x}$ & $\mathrm{x}$ & - & - \\
\hline Eubacteriaceae & Eubacterium & - & $\mathrm{x}$ & - & - \\
\hline Alcaligenaceae & Bordetella & - & - & $\mathrm{x}$ & - \\
\hline Microccocceae & Micrococcus & - & - & - & $\mathrm{x}$ \\
\hline Stapylococceae & Staphylococcus & - & - & - & $\mathrm{x}$ \\
\hline Clostridiaceae & Clostridium & - & $\mathrm{x}$ & - & - \\
\hline Neisseriaceae & Neisseria & - & - & $\mathrm{x}$ & - \\
\hline
\end{tabular}

Keterangan: simbol x menunjukkan genus bakteri yang ditemukan

sistem mangrove melalui pengurai dekomposisi serasah yang menyebabkan bakteri dapat tumbuh dan bertahan hidup (Yunasfi et al., 2006). Bakteri Bacillus yang ditemukan lebih banyak karena bakteri ini berada di permukaan. Berdasarkan penelitian sebelumnya oleh Min-han et al. (2000) menyatakan bahwa rata-rata proses dekomposisi terjadi di permukaan sedimen mangrove lebih efektif dibandingkan di dalam sedimen. Sedimen permukaan merupakan kawasan yang sangat efektif dalam menyumbangkan nutrien ke dalam lingkungan perairan sekitarnya. Hal ini disebabkan karena potensi terbentuknya kondisi aerob lebih besar (Jianfang et al., 2003).

Dalam kondisi demikian proses perombakan bahan organik mempunyai peluang besar dapat terjadi melalui penyediaan bahan pengoksidasi khususnya oksigen. Atas dasar hal tersebut maka lingkungan permukaan mangrove mempunyai peran penting yang sangat besar tidak saja dalam menunjang terbentuknya pertumbuhan kawasan mangrove itu sendiri, namun juga sebagai pe- nyumbang nutrien yang efektif terhadap lingkungan sekitarnya.

Bacillus secara alami ditemukan di dalam sedimen karena kemampuannya menghasilkan endospora, selain itu Bacillus juga dapat menghadapi berbagai perubahan lingkungan, seperti perubahan kadar nutrien, air, dan temperatur (Madigan et al., 2004). Karakteristik ini menyebabkan Bacillus dapat ditemukan di berbagai tempat termasuk di dalam sedimen. Bacillus memiliki peran penting dalam siklus biologis karbon dan nitrogen, karena dapat secara efektif mendegradasi serangkaian polimer seperti hemiselulosa, pektin, kitin, dan protein (Holt et al., 1994). Selain itu, bakteri Bacillus diduga dapat dijadikan indikator dalam penentu sedimen yang mengandung limbah tinggi.

Bakteri yang paling sedikit ditemukan adalah Neisseria, hal ini diduga karena faktor lingkungan salah satunya adalah suhu, bakteri Neisseria hidup pada suhu optimum antara $35^{\circ} \mathrm{C}-37^{\circ} \mathrm{C}$ sedangkan pengukuran suhu di lokasi didapatkan nilai $28,9^{\circ} \mathrm{C}$, hal ini sesuai dengan pernyataan Cowan et al. (1965) bahwa genus Neisseria memiliki temperatur optimum hidup dan tumbuh $35^{\circ} \mathrm{C}-37^{\circ} \mathrm{C}$ dan beberapa spesies bersifat patogen terhadap manusia. Selain itu bakteri ini memiliki aktivitas enzim hidrolitik pada substrat selulosa asetat, CMC dan xylan, namun aktivitas enzim hidrolitik tidak tampak pada sedimen. Selain itu bakteri Neisseria juga ditemukan paling sedikit pada daun mangrove yang terdekomposisi pada penelitian Yulma et al. (2017). Hasil penelitian pada setiap stasiun terlihat bahwa bakteri Bacillus ditemukan disemua stasiun dan setiap stasiun memiliki dominansi bakteri yang ber- 
Tabel 2 Dominansi bakteri sedimen pada setiap stasiun penelitian

\begin{tabular}{cccccc}
\hline \multirow{2}{*}{ Bakteri (Genus) } & \multicolumn{4}{c}{ Stasiun } & Jumlah Bakteri \\
\cline { 2 - 5 } & I & II & III & IV & (Koloni) \\
\hline Bacillus & 6 & 16 & 5 & 8 & 35 \\
Aeromonas & 0 & 0 & 0 & 17 & 17 \\
Bacteriodes & 0 & 4 & 13 & 0 & 17 \\
Listeria & 8 & 7 & 0 & 2 & 17 \\
Corynebacterium & 4 & 0 & 11 & 0 & 15 \\
Enterobacteria & 11 & 0 & 3 & 0 & 14 \\
Plesiomonas & 14 & 0 & 0 & 0 & 14 \\
Streptococcus & 5 & 8 & 0 & 0 & 13 \\
Actinobacillus & 0 & 2 & 3 & 4 & 9 \\
Pseudomonas & 2 & 5 & 0 & 0 & 7 \\
Eubacterium & 0 & 5 & 0 & 0 & 5 \\
Bordetella parapertussis & 0 & 0 & 4 & 0 & 4 \\
Micrococcus & 0 & 0 & 0 & 4 & 4 \\
Staphylococcus & 0 & 0 & 0 & 4 & 4 \\
Clostridium & 0 & 3 & 0 & 0 & 3 \\
Neisseria & 0 & 0 & 1 & 0 & 1 \\
\hline
\end{tabular}

beda berdasarkan vegetasi mangrove seperti pada Tabel 2 .

Bakteri yang paling dominan ditemukan pada stasiun I adalah Plesiomonas. Banyaknya bakteri Plesiomonas ini diduga karena pengaruh suhu di lokasi penelitian. Pengujian parameter suhu adalah $26,9^{\circ} \mathrm{C}-30^{\circ} \mathrm{C}$, dimana suhu yang didapatkan merupakan suhu normal untuk laju pertumbuhan karena berada di atas batas suhu minimum bakteri Pleisiomonas tumbuh. Hal ini merujuk pada pernyataan Suhendi (2009) bahwa bakteri Pleisiomonas tidak dapat tumbuh pada suhu di bawah $8^{\circ} \mathrm{C}-10^{\circ} \mathrm{C}$. Dominannya bakteri Plesiomonas ini selain disebabkan oleh suhu, juga dipengaruhi oleh kadar $\mathrm{pH}$. Nilai $\mathrm{pH}$ pada penelitian ini berkisar 6,7 - 7,5, nilai ini sesuai untuk pertumbuhan bakteri. Ratledge (2012) menyatakan bahwa nilai $\mathrm{pH}$ optimum untuk pertumbuhan bakteri adalah berkisar antara 7,5 8,5 .

Pada stasiun II jumlah bakteri yang paling dominan adalah Bacillus hal ini diduga karena Bacillus hidup dan tumbuh pada kisaran suhu optimum yakni
$28,2{ }^{\circ} \mathrm{C}-32{ }^{\circ} \mathrm{C}$. Sesuai dengan pernyataan Imron and Purwanti (2016) bahwa suhu yang terukur untuk Bacillus berkisar antara $27,6{ }^{\circ} \mathrm{C}-32{ }^{\circ} \mathrm{C}$. Selain parameter suhu, bakteri Bacillus juga dapat dipengaruhi oleh faktor $\mathrm{pH}$. Bakteri Bacillus hidup dan tumbuh pada kondisi $\mathrm{pH}$ berkisar antara $6-7$. Nilai $\mathrm{pH}$ di stasiun II adalah 6,7 - 7,5, dimana nilai $\mathrm{pH}$ tersebut sesuai untuk pertumbuhan bakteri Bacillus. Bacillus rata-rata tumbuh pada $\mathrm{pH}$ dengan kisaran antara $6-7$, dimana $\mathrm{pH}$ tersebut sesuai dengan $\mathrm{pH}$ di alam yaitu 6,3. Hal ini menunjukkan bahwa semua genus bakteri termasuk dalam golongan Neutrophil yaitu bakteri yang dapat hidup pada rentang $\mathrm{pH} 5.5$ - 8.0.

Bakteri yang dominan pada stasiun III adalah bakteri Bacteriodes dan Corynebacterium, hal ini diduga karena bakteri ini dapat hidup pada suhu $26,9^{\circ} \mathrm{C}$ - 29, $1^{\circ} \mathrm{C}$. Indriani (2008) menyatakan bahwa suhu optimum untuk bakteri berkisar $27^{\circ} \mathrm{C}-36{ }^{\circ} \mathrm{C}$. Kondisi lingkungan yang selalu berubah-ubah dan umumnya dapat hidup pada kondisi anaerob fakultatif sehingga bakteri ini paling dominan dijumpai pada stasiun ini. Sesuai dengan pernyataan Suliasih (2007) bahwa bakteri Corynebacterium ini umumnya hidup pada kondisi anaerob dan memiliki kemampuan dalam membentuk spora sehingga sangat menguntungkan bagi bakteri sedimen terkait dengan kondisi lingkungannya yang selalu berubahubah.

Pada stasiun IV bakteri yang dominan ditemukan adalah Aeromonas, hal ini diduga karena bakteri Aeromonas dapat tumbuh dan hidup pada suhu berkisar antara $22{ }^{\circ} \mathrm{C}-30{ }^{\circ} \mathrm{C}$. Suhu pada stasiun IV berkisar antara $26,9{ }^{\circ} \mathrm{C}$ - $29,1^{\circ} \mathrm{C}$, dimana nilai suhu ini men- 
Tabel 3 Perbedaan bakteri sedimen mangrove di KKMB dengan daerah lainnya

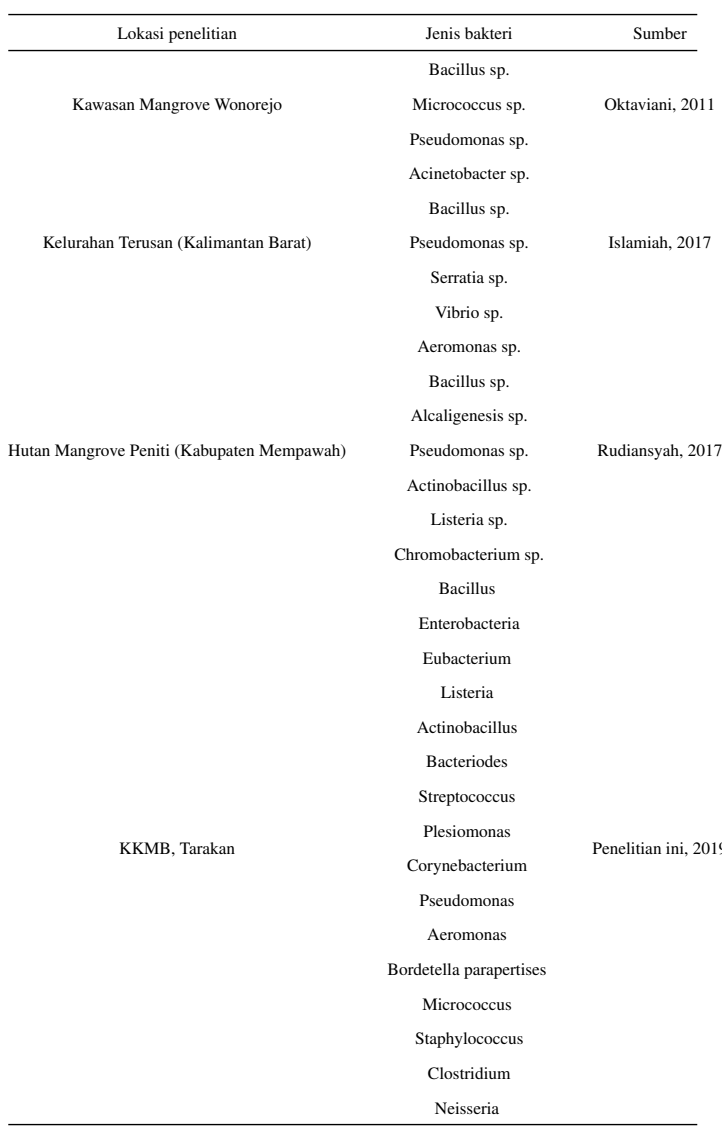

dekati dengan nilai optimum sehingga bakteri Aeromonas banyak ditemukan pada stasiun IV. Bakteri Aeromonas bahkan dapat hidup pada suhu tinggi mencapai $37^{\circ} \mathrm{C}$ sesuai dengan pendapat Holt et al. (1994) bahwa genus Aeromonas bersifat motil dan dapat hidup pada kondisi aerob. Suhu optimum untuk pertumbuhannya yaitu $22^{\circ} \mathrm{C}$, tetapi sebagian besar bakteri ini tumbuh baik pada suhu $37{ }^{\circ} \mathrm{C}$.

Bakteri yang ditemukan pada sedimen di KKMB yaitu 16 genus, hasil ini berbeda dengan penelitian dari beberapa daerah lainnya (Tabel 3).

Faktor yang menyebabkan perbedaan jumlah genus bakteri di beberapa lokasi penelitian diduga karena keterse- diaan unsur hara, $\mathrm{N}$ dan $\mathrm{F}$ yang terdapat pada sedimen. Yulma et al. (2018b) mendapatkan hasil kandungan bahan organik Nitrogen pada sedimen KKMB berkisar 0,31-0,55 dikategorikan memiliki kandungan yang tinggi hal ini sesuai dengan penelitian dari Bappeda Kendal (2012) dalam Chrisyariati et al. (2014) bahwa kandungan $\mathrm{N}$-total dengan nilai 0-0,20 adalah rendah dan kisaran 0,21-0,40 adalah sedang (cukup) dan diatas kisaran 0,40 adalah tinggi. Selain itu, perbedaan jenis mangrove dan faktor lingkungan juga mempengaruhi keberadaan bakteri pada sedimen. Sesuai dengan pernyataan Hrenović et al. (2003) bahwa faktor yang menyebabkan perbedaan jumlah genus yaitu faktor lingkungan perairan yang meliputi $\mathrm{pH}$, suhu, substrat, salinitas dan letak geografis.

Pengukuran parameter kualitas air yang dilakukan meliputi parameter fisika-kimia perairan yang diukur adalah suhu, salinitas, $\mathrm{pH}$, dan oksigen terlarut (DO). Parameter fisika-kimia tersebut diduga berpengaruh terhadap bakteri. Perbedaan bakteri disebabkan oleh faktor lingkungan (suhu, salinitas, kadar $\mathrm{pH}$ ) dan kehadiran mikroorganisme pengurai dan makrobentos yang terdapat dikawasan hutan mangrove. Hasil pengukuran parameter fisika - kimia di KKMB pada Tabel 4.

Nilai salinitas di KKMB berkisar 27$30 \%$, hal ini sejalan dengan penelitian Yunasfi et al. (2006) bahwa tingkat salinitas yang tinggi akan memberikan efek negatif terhadap kelimpahan dan keanekaragaman bakteri. Tingginya tingkat salinitas mampu menghambat pertumbuhan koloni bakteri sehingga menyebabkan tingkat aktivitas bakteri sangat rendah akibatnya terja- 
di shock osmotic atau toksik (Mallin et al., 2000). Hasil pengukuran suhu di KKMB berkisar antara $26,9{ }^{\circ} \mathrm{C}-32$ ${ }^{\circ} \mathrm{C}$, suhu yang diperoleh dalam penelitian ini masih berada dalam kisaran yang baik untuk proses pertumbuhan bakteri pada sedimen. Indriani (2008) menyatakan suhu optimum untuk bakteri berkisar $27{ }^{\circ} \mathrm{C}-36{ }^{\circ} \mathrm{C}$. Kisaran suhu tersebut sangat baik untuk proses pertumbuhan bakteri.

Nilai pH di KKMB berkisar 6,5 - 7,8, nilai ini masih mendukung untuk pertumbuhan bakteri. Tait (1981) menyatakan bahwa kisaran $\mathrm{pH}$ optimum untuk pertumbuhan mikroorganisme adalah 5,6 - 9,4. Nilai kandungan oksigen terlarut (DO) di KKMB berkisar 1,07 $\mathrm{mg} / \mathrm{L}$ - 6,15 mg/L, hal ini menunjukkan bahwa DO perairan di KKMB masih tergolong baik. Umumnya nilai oksigen terlarut di ekosistem mangrove rendah, hal ini disebabkan karena meningkatnya bahan-bahan organik serta dapat dipengaruhi oleh kenaikan suhu, salinitas, respirasi (Reid, 1961; Welsch, 1952). Kandungan DO dalam air mempunyai peranan untuk menentukan kelangsungan hidup organisme akuatik dan untuk berlangsungnya peroses reaksi kimia yang terjadi di dalam badan perairan. Patty (2013) menyatakan bahwa pada umumnya kandungan DO sebesar $5 \mathrm{mg} / \mathrm{L}$ dengan suhu air berkisar antara $20{ }^{\circ} \mathrm{C}-32^{\circ} \mathrm{C}$ relatif masih baik untuk biota laut, bahkan apabila dalam perairan tidak terdapat senyawa-senyawa yang bersifat toksik (tidak tercemar) kandungan DO sebesar $2 \mathrm{mg} / \mathrm{L}$ sudah cukup untuk mendukung kehidupan organisme perairan.

\section{SIMPULAN}

Bakteri yang ditemukan pada sedimen di KKMB sebanyak 16 genus yaitu $E n$ terobacteria, Eubacterium, Listeria, Actinobacillus, Bacteriodes, Streptococcus, Plesiomonas, Corynebacterium, Pseudomonas, Aeromonas, Bordetella parapertussis, Micrococcus, Staphylococcus, Clostridium, Neisseria dan yang lebih dominan ditemukan yaitu Bacillus.

Acknowledgements Penelitian ini didanai oleh DIPA Universitas Borneo Tarakan Anggaran 2018 melalui LPPM UBT.

\section{Pustaka}

Bissett, A., Burke, C., Cook, P. L., and Bowman, J. P. (2007). Bacterial community shifts in organically perturbed sediments. Environmental Microbiology, 9(1):46-60.

Chrisyariati, I., Hendrarto, B., et al. (2014). Kandungan nitrogen total dan fosfat sedimen mangrove pada umur yang berbeda di lingkungan pertambakan mangunharjo, semarang. Management of Aquatic Resources Journal, 3(3):65-72.

Cowan, S. T., Steel, K. J., et al. (1965). Manual for the identification of medical bacteria. Manual for the identification of medical bacteria.

Holt, J. G., Krieg, N., Sneath, P. H., Staley, J., and Williams, S. (1994). Bergeyï̈œs manual of determinative bacteriology. 9th. Baltimor: William \& Wilkins.

Hrenović, J., Viličić, D., and Stilinović, B. (2003). Influence of nutrients and salinity on heterotrophic and coliform bacteria in the shallow, kars- 
tic zrmanja estuary (eastern adriatic sea). Ekoloji, The Journal of Environemnt, 12(46):29-37.

Imron, M. F. and Purwanti, I. F. (2016). Uji kemampuan bakteri azotobacter s8 dan bacillus subtilis untuk menyisihkan trivalent chromium (cr3+) pada limbah cair. Jurnal Teknik ITS, 5(1).

Indriani, Y. (2008). Produksi dan laju dekomposisi serasah daun mangrove api-api (avicennia marina forssk. vierh) di desa lontar, kecamatan kemiri, kabupaten tangerang, provinsi banten. Skripsi. Program Studi Ilmu Dan Teknologi Kelautan, Fakultas Perikanan Dan Ilmu Kelautan, Institut Pertanian Bogor. Bogor.

Jianfang, C., Haiyan, J., Kedong, Y., and Yan, L. (2003). Variation of reactivity of particulate and sedimentary organic matter along the zhujiang river estuary. ACTA OCEANOLOGICA SINICAENGLISH EDITION-, 22(4):557568.

Madigan, M., Martinko, J., and Parker, J. (2004). Brock biology of microorganisms, 2003. New Jearsey Pearson Education, pages 178-185.

Maier, R. M., Pepper, I. L., and Gerba, C. P. (2009). Environmental microbiology, volume 397. Academic press.

Mallin, M. A., Williams, K. E., Esham, E. C., and Lowe, R. P. (2000). Effect of human development on bacteriological water quality in coastal watersheds. Ecological applications, 10(4):1047-1056.

Min-han, D., Martin, J.-M., Huasheng, H., and Zu-lin, Z. (2000). Preliminary study on the dissolved and colloidal organic carbon in the zhujiang river estuary. Chinese Jo- urnal of Oceanology and Limnology, 18(3):265-273.

Patty, S. I. (2013). Distribusi suhu, salinitas dan oksigen terlarut di perairan kema, sulawesi utara. Jurnal Ilmiah Platax, 1(3):148-157.

Purnomo, P. W., Widyorini, N., Ain, C., and Undip, F. (2016). Analisis $\mathrm{c} / \mathrm{n}$ rasio dan total bakteri pada sedimen kawasan konservasi mangrove sempadan sungai betahwalang dan sungai jajar demak.

Rangkuti, A. M., Reza, M., Ani, C., Yulma, R., and Hasan, E. A. (2017). Ekosistem Pesisir dan Laut Indonesia. Bumi Aksara, Jakarta.

Ratledge, C. (2012). Biochemistry of microbial degradation. Springer Science \& Business Media.

Reid, G. K. (1961). Ecology of inland waters and estuaries.

Romimohtarto, K. and Juwana, S. (2001). Biologi laut: Ilmu pengetahuan tentang biota laut. Djambatan.

Saparinto, C. (2007). Pendayagunaan ekosistem mangrove. Dahara Prize. Semarang, 236.

Suhendi (2009). Identifikasi dan prevalensi bakteri dan cendawan yang terseleksi serta parasit pada ikan arwana super set scleropages fosmosus yang sakit. Jurnal Budidaya Perairan, 5(3):11-17.

Suliasih, R. (2007). Aktivitas fosfatase dan pelarutan kalsium fosfat oleh beberapa bakteri pelarut fosfat. Biodiversitas, 8(1):23-26.

Welsch, P. S. (1952). Limnology. McGraw-Hill Book Company, Inc.; New York.

Yulma, Y., Ihsan, B., and Rafikah, A. (2018a). Keanekaragaman bakteri pada perairan di kawasan konservasi mangrove dan bekantan $(\mathrm{kkmb})$ kota tarakan. JURNAL BORNEO SAIN- 
TEK, 1(3):55-62.

Yulma, Y., Ihsan, B., Sunarti, S., Malasari, E., Wahyuni, N., and Mursyban, M. (2017). Identifikasi bakteri pada serasah daun mangrove yang terdekomposisi di kawasan konservasi mangrove dan bekantan (kkmb) kota tarakan. Journal of Tropical Biodiversity and Biotechnology, 2(1):2833.

Yulma, Y., Salim, G., and Sampe, Y. (2018b). Analisis bahan organik nitrogen (n) dan fosfor ( $p$ ) pada sedimen di kawasan konservasi mangrove dan bekantan (kkmb) kota tarakan. JURNAL BORNEO SAINTEK, 1(2):75-82.

Yunasfi, S. H., Kusmana, C., Sudirman, L., and Tjahjono, B. (2006). Dekomposisi serasah daun a. marina oleh bakteri dan fungi pada berbagai tingkat salinitas. Disertasi). Sekolah Pascasarjana Institut Pertanian Bogor. Bogor. 
